\title{
El hallazgo del escrito oculto en la literatura española del Siglo de Oro: elementos para una mitología del Libro
}

\section{ManusCRitos ocultos EN El QUIJOTE}

No dejó de llamarles la atención a los más atentos lectores del Quijote el que Cervantes recurriera dos veces al motivo novelesco del descubrimiento de un libro o documento oculto, y el que los episodios correspondientes desempeñaran un destacado papel de transición o modificación de la perspectiva narrativa.

1.1. Después de la batalla entre el valiente manchego y el gallardo vizcaíno se introduce en efecto a Cide Hamete Benengeli mediante el descubrimiento por el presunto "autor" de los capítulos anteriores de un cartapacio comprado por él en el Alcana de Toledo a un muchacho que estaba vendiendo papeles viejos a un sedero. Dicho cartapacio contiene el manuscrito árabe del relato de Cide Hamete, el cual vendrá a ser, después de su debida traducción por un "morisco aljamiado", la base referencial en cuanto a la continuación de las aventuras del ingenioso hidalgo ${ }^{1}$. No se trata, en el sentido estricto, de un libro oculto pero sí viene a colmar la inopinada aparición del cartapacio la supuesta carencia documental que detiene al apesadumbrado narrador "en aquel punto tan dudoso", dejando "manca y estropeada" la "gallarda historia" del valiente y peregrino manchego.

1.2. Más explícita y característica es la segunda aparición del motivo, con la que se cierra el libro de 1605. Otra vez afectado por la ausencia de "escrituras auténticas", el "autor desta historia" (¿se tratará ahora de Cide Hamete?) se encuentra en el mismo aprieto de los ocho primeros capítulos, y en la incapacidad de relatar "los hechos que don Quijote hizo en su tercera salida ${ }^{2}$. Y otra vez la buena suerte lo viene a socorrer en la persona de "un antiguo médico que tenía en su poder una caja de plomo que, según él dijo, se había hallado en los cimientos derribados de

1 Don Quijote I, 9. Sobre las perspectivas narrativas en el Quijote véase Michel Moner, Cervantes conteur. Ecrits et Paroles (Madrid: Casa de Velázquez, 1989), cap. 3.

2 Don Quijote I, 52. 
una antigua ermita que se renovaba; en la cual caja se habían hallado unos pergaminos escritos con letras góticas, pero en versos castellanos (...). Dichos pergaminos contenían al parecer los epitafios reproducidos a continuación y algunos versos más que, "por estar carcomida la letra, se entregaron a un académico para que por conjeturas los declarase".

En la Segunda Parte no se volverán a mencionar estos documentos y, como si nada sucediera, se continúa contando las aventuras de Don Quijote bajo la máscara de un Cide Hamete Benengeli nada cohibido, al parecer, por el vacío documental aludido al final del libro anterior.

1.3. En ambos casos un fingido hueco en la materia narrativa se remedia mediante el concurso de un texto oculto que, casi milagrosamente, aparece en el momento en que más se necesita. En ambos casos se trata de textos de indefinidos antigüedad y orígenes: "papeles viejos" entre los cuales se encuentra el precioso cartapacio y "antigua ermita" en cuyos cimientos se hallan los "pergaminos escritos en letras góticas" (incluso es viejo el "antiguo médico" que los tiene en su poder).

Finalmente, en ambos casos, es preciso acudir a un intermediario -traductor o académico- que aclare el contenido de dichos textos, ya que ambos se caracterizan por su opacidad o hermetismo, por causa del idioma y caracteres (aljamía arábiga del cartapacio) o por el mal estado de conservación (pergamino carcomido).

\section{APÓCRIFOS EN GRANADA}

2.1. No han dejado de notar los más atinados cervantistas —entre ellos Américo Castro y Michel Moner- que estos episodios, en particular el segundo, parecen entrañar alguna socarrona alusión a los famosos y casi contemporáneos "descubrimientos" de los apócrifos manuscritos granadinos entre los que figuraban los "plomos", cajas, pergaminos y reliquias de la Torre Turpiana y del Sacromonte ${ }^{3}$.

Hoy sabemos que estos místicos, proféticos e indudablemente falsos documentos fueron elaborados por moriscos deseosos de establecer vín-

\footnotetext{
3 Wéanse Michel Moner, "La descente aux enfers de Don quichotte: faussey chrohiques et lextes apoeryphes avec đuelques éhigmes à ha clé, fommage à Robelt Jammes (Toulowse: PUM, 1994), t. 3, pp. 849-853, "Cervantes y la traducción Nuev Revista de Filología Hispánica, 38, 2 (1990); pp. 513-524, y Américo CASTRO, "Cómo veo ahora el Quijote" (estudio preliminar a la edición del Quijote publicada por Editorial Magisterio Español (Madrid, 1971), t. 1, pp. 9-102. Sobre la historia de las falsificaciones granadinas se puede leer el libro de Carlos Alonso, Los apócrifos del Sacromonte (Granada). Estudio bistórico (Valladolid: Estudio Agustiniano, 1979).
} 
culos entre la ortodoxia cristiana, las expresiones de la devoción local, y algún que otro elemento del mundo credencial musulmán.

Además se han querido ver, probablemente con razón, relaciones entre el contenido de algunos de estos documentos y ciertos episodios del Quijote (como los de la Cueva de Montesinos, Clavileño y las aventuras subterráneas de Sancho en la ínsula Barataria) ${ }^{4}$.

Lo que sí es seguro es que, en su trabajo de falseamiento, los autores de la superchería pusieron en ejecución un modelo imaginario ya fuertemente arraigado en las representaciones colectivas de la España de fines del siglo XVI, en la que florecían los "falsos cronicones" y las ansias mesiánicas. El amplio y duradero éxito de esta empresa de ilusionismo religioso, la inesperada aceptación que tuvo en casi todos los sectores de la sociedad aurisecular (la cual produjo, inconsciente y espontáneamente, colaboradores de buena o mala fe en el proceso de difusión y promoción del engaño: descubridores más o menos inopinados de los documentos enterrados, intérpretes, comentaristas etc...), la docilidad de la ingenua mayoría en adoptar los esquemas de creencia, de comportamiento y de adhesión intelectual que se le proponían, prueban que la escenografía maquinada por el reducido grupo de falseadores correspondía a un estereotipo mental de vasta difusión. Un estereotipo susceptible de ser compartido por los más adocenados y milagreros devotos y por los eruditos más pertrechados de autoridades y referencias ${ }^{5}$. Un dispositivo imaginario admitido de igual modo, en fin, por supersticiosos e ignorantes buscadores de tesoros que por teólogos y humanistas.

2.2. El elemento clave del hallazgo de los apócrifos de Granada era, lo mismo que en el Quijote, el motivo del libro ocultado y descubierto; $\mathrm{y}$, como en los episodios cervantinos ya aludidos, los documentos desenterrados eran antiguos, estaban repletos de revelaciones históricas importantes e inéditas, y necesitaban el correspondiente descifrado y traducción.

En el caso de los apócrifos granadinos se añadían sin embargo, tanto al contenido de los escritos como a las circunstancias a la vez inopinadas y casi milagrosas de su descubrimiento, varios componentes místicos (el tema del viaje sobrenatural en el Libro del coloquio de Santa María Virgen; la coexistencia de los textos con reliquias materiales y corporales de santos mártires; las profecías, etc.). Pero estos componentes, ausentes de

\footnotetext{
4 M. MONER, "La descente aux enfers...", pp. 552 y ss.

5 Notable ejemplo de coincidencia entre crasa credulidad y acendrada erudición se encuentra por ejemplo en los razonamientos del Discurso de la certidumbre de las Reliquias descubiertas en Granada de Gregorio López Madera (Granada, 1601).
} 
los mentados capítulos del Quijote, se encuentran traspuestos en clave paródica, en otros episodios de la novela (el de la Cueva de Montesinos etc.), tal como ha señalado Michel Moner.

\section{UN TÓPICO DE LA RETÓRICA NARRATIVA}

3.1. La críptica alusión cervantina a los apócrifos granadinos -más a los de la Torre Turpiana que a los del Sacromonte- parece por lo tanto evidente. Se podría deducir en consecuencia que, al reflejarse en el Quijote, el motivo del libro ocultado y descubierto - que conoció una prodigiosa vida metaliteraria y religiosa en el caso de los plomos andalucesvolvía a su medio ambiente natural de la retórica narrativa y de la prosa de ficción.

No se puede negar, en efecto, que se trata de un difundido tópico literario: aunque es cierto que Cervantes se inspiró en los acontecimientos granadinos, también es patente que recurrió, en las mencionadas páginas, a un motivo narrativo tradicional. También cabe suponer que los autores de los apócrifos aprovecharon el mismo motivo, al que consiguieron conferir existencia concreta, y que no hicieron más que trasponer aa lo divino" un motivo narrativo latente del que Cervantes daría una visión más bien irónica y crítica.

Aquí quiero esbozar una arqueología de las formas españolas auriseculares de este tópico, y poner de manifiesto que detrás de tal recurso retórico-narrativo se puede entrever un verdadero tipo legendario cuyas raíces y facetas míticas explican en parte que haya podido ser usado en contextos tan dispares.

3.2. A primera vista, la referencia hecha por un autor cualquiera al descubrimiento de un manuscrito que facilitó la materia del libro (o parte de ella) - mediante la correspondiente traducción o adaptación - se presenta como una triquiñuela ficticia y convencional, de dimensión puramente lúdica o estilística. Puede ser que se tome en serio (o que se finja tomar en serio, como puede ocurrir en algún que otro "falso cronicón"): en estos casos, frecuentes en la literatura narrativa medieval —en la que se menciona a menudo que, por ejemplo, la materia de tal o cual historia se ha encontrado en un manuscrito descubierto en el archivo de un monasterio o en la biblioteca de una iglesia ${ }^{6}$, la referencia verídica 0

6 Edmond Faral, Les jongleurs en France au Moyen-Age (Paris, 1910), pp. 170-172. Véase tambien Pierre-Yves BADEL, "Rhétorique et Polémique dans les prologues de 
fingida al original más o menos oculto que se pretende divulgar no es más que un medio de conferir autenticidad y antigüedad, y por lo tanto autoridad y prestigio, al texto que el lector tiene en sus manos. No importa, al fin y al cabo, que exista o no el texto aludido, que sea verdad o patraña lo de su presunto "descubrimiento". Lo que cuenta en los prólogos denegativos o "cripto-auctoriales", en los que el autor, seria o jocosamente, atribuye a otro la paternidad del texto que está ofreciendo al público, es el espacio de fingida o real intertextualidad que se está abriendo, los efectos de perspectivismo y distanciación que se facilitan, la manipulación de los puntos de referencia y de connivencia mental del lector ${ }^{7}$.

Claro está que cuando las atribuciones mencionadas en los seudoalógrafos son deliberadamente ficticias ya lindamos con el universo de las falsificaciones y de la literatura apócrifa. Pero entre el engaño puro y la ficción lúdica media todo un espacio de libertad literaria en el que el organizador de la materia narrativa - ya se presente como autor o como mero transcriptor - puede aprovechar los desajustes que él mismo utiliza para controlar los enfoques y relativizar los puntos de vista ${ }^{8}$. El motivo del libro oculto y descubierto viene así a constituir uno de los elementos esenciales del dispositivo prologal y paratextual movilizado por los autores - con excepcional frecuencia en los del Siglo de Oro español- para producir determinados efectos ideológicos y literarios ${ }^{9}$.

3.3. El procedimiento es de especial relevancia en las novelas de caballerías. Ya se sabe que muchas de las hispánicas simulan ser "historias", y que sus autores fingen que sus libros no son más que "traducciones" de libros antiguos, las más de las veces redactados en idiomas antiguos y/o exóticos ${ }^{10}$.

romans au Moyen-Age", Littérature, 20 (1975), pp. 81-94 (en particular pp. 90 y ss.). Sobre la retórica de los prólogos en la Edad Media: Ernst Robert CuRTius, European Literature and the Latin Middle Ages (Nueva York: Harper and Row, 1963), pp. 85-89.

7 Gérard Genetre, Seuils (Paris: Seuil, 1987), pp. 156, 171 y ss.; 256 y ss.

8 Id., Palimpsestes. La littérature au second degré (Paris: Seuil, 1982) (panorama de las prácticas «hipertextuales", es decir de "toutes les oeuvres dérivées d'une oeuvre antérieure, par transformation ou par imitation"). La seudo-atribución pudiera considerarse como una especie de hiper-textualidad ficticia.

9 Véase el excelente libro de Anne Cayuela, Le Paratexte au Siècle d'Or. Prose romanesque, livres et lecteurs en Espagne au xvième siècle (Genève: Droz, 1996), pese a que no se estudia en él el motivo paratextual al que se dedica el presente ensayo.

10 Daniel EISENBERG, "The pseudo-historicity of the Romances of Chivalry", Romances of Chivalry in the Spanish Golden Age (Newark, 1982), pp. 119-129. Véase también 
Ahora bien, en algunos casos se hace más explícita aún esta ficción al contar el autor (o seudo-traductor) las circunstancias del descubrimiento del libro original - griego, árabe, latino, etc.- que ha traducido en castellano.

Lo más frecuente es que el manuscrito se haya encontrado en algún lugar fantástico más o menos relacionado con el mundo subterráneo. Montalvo finge así que el libro cuarto del Amadis y las Sergas de Esplandián fueron descubiertos aen una tumba de piedra que debaxo de la tierra en una hermita cerca de Constantinopla fue halladan: traídos a España por un mercader húngaro fueron traducidos (del griego) a pesar de su uletra y pergamino tan antiguo que con mucho trabajo se pudo leer por aquellos que la lengua sabían" ${ }^{11}$. Mediante este tipo de artificio se combinan la afición a la novedad (exigida a toda "novela") y el prestigio de la antigüedad "histórica", ya que el primer "autor" se supone más o menos contemporáneo e incluso testigo presencial de las aventuras de los personajes que salen en el libro.

A veces se construye una especie de "novela en segundo grado" en la cual se cuenta cómo el editor o traductor (ya que se niega a presentarse como autor) tuvo conocimiento de la materia y a veces del mismo texto de su libro.

En estos casos son de notar por una parte el aspecto onírico, fantástico y casi místico de la experiencia mental mediante la cual adquirió el conocimiento de dicha materia, y, por otra, la recurrencia del motivo de la proveniencia subterránea: al final del primer libro del Amadis de Grecia, Feliciano de Silva cuenta por ejemplo cómo, en un "Sueño" en el que se entrevista con el dios del Amor y con su amada, se entera de que hallará el texto de la segunda parte de las aventuras de Amadís "en una cueva que se llama los Palacios de Hércules, metida en una caxa de madera, que no se corrompe, en un lado de la pared; porque quando España fue perdida la escondieron en aquel lugar, porque la memoria destos cavalleros no se perdiesse ${ }^{12}$; del mismo modo el autor de la Tercera parte del Espejo de príncipes y caballeros cuenta cómo recibió, duran-

María Carmen MARín PINA, "El tópico de la falsa traducción en los libros de caballerías españoles", Actas del III Congreso de la Asociación Hispánica de Literatura Medieval (Salamanca, 1994), t. 1, pp. 541-548; M. MONER, "Cervantes y la traducción" y Henry ThOmas, Spanish and Portuguese Romances of Chivalry (Cambridge, 1920), p. 13.

11 Amadis de Gaula (ed. J. M. Cacho Blecua) (Madrid: Cátedra, 1987), t. 1, pp. 224 y ss. Un cuento análogo introduce el relato de las aventuras de Perceforest: Le Roman de Perceforest, Première Partie, J.H.M. Taylor ed. (Genève: Droz, 1979), pp. 121-123.

12 Véase D. EISENBERG, "Amadis de Gaula and Amadis de Grecia. In defense of Feliciano de Silva", Romances of Chivalry..., pp. 75-85 (p. 84). 
te sus mágicas aventuras en la Cueva de Sifronio de Anglante (cerca de Alcalá de Henares) el libro que tendrá que traducir ${ }^{13}$; aventuras análogas se pueden leer en el Olivante de Laura de Torquemada y en el Febo el Troyano de Esteván de Corvera, a cuyos autores-traductores se entregan los manuscritos mientras están realizando un viaje mágico por el más allá ${ }^{14}$.

3.4. Claras reminiscencias de este tipo de ficción entraña el episodio quijotesco de la Cueva de Montesinos, aunque Don Quijote no recibe ningún manuscrito durante su estancia en la cueva: Cervantes ha traspuesto el motivo al plano "real" y, como hemos visto, ha reservado para Cide Hamete el descubrimiento del texto oculto.

Ya se ha subrayado la relación que existe entre la aventura subterránea del ingenioso hidalgo y el capítulo 99 de Las Sergas en el que Montalvo finge que tuvo en sueños la revelación que le permitió conocer el final de la historia de Esplandián ${ }^{15}$ : guiado por Urganda la Desconocida en el mundo de ultratumba donde residen (mantenidos fuera del tiempo en un estado de supervivencia mágica) los heroicos caballeros destinados a reunirse con el rey Arturo el día de su gran retorno escatológico, el novelista medinés entra en contacto directo con el verdadero autor de la historia de Esplandián, el maestro Elisabat, que se le aparece con su libro entre manos; la sobrina de Urganda se lo traduce oralmente (del griego) y Montalvo ya no tendrá más que grabar en su memoria y redactar el texto así revelado.

En este episodio se combinan sueño, visión sobrenatural, viaje iniciático por el más allá, descubrimiento de un libro oculto y descenso al mundo subterráneo, ya que el acceso al mundo maravilloso y recóndito donde se encuentran reunidos en un mismo espacio los héroes caballerescos, el primer cronista de sus hazañas y el texto original que servirá de fuente y modelo a la novela de Montalvo, implica que éste baje al fondo de una cueva y, después de su viaje visionario, sea devuelto por el mismo camino al mundo de los vivos.

Ya se ve que estas ficciones estriban en la combinación de dos componentes que también fueron estrechamente asociados por los falsificadores de Granada: un elemento de biblio-arqueología imaginaria (el tópico del antiguo manuscrito ocultado -encontrado- traducido) y un motivo místico-visionario (esquema narrativo del viaje al más allá y de la revelación),

13 Id., "The pseudo-historicity...", p. 126.

14 M. C. Marín PINA, op. cit., p. 545.

15 Cap. 99 (pp. 497-501 de la edición de la BAE 40, Libros de Caballerías). Véase M. R. LIDA DE MALKIEL, "Dos huellas del Esplandián en el Quijote y en el Persiles", Romance Pbilology, 9 (1955-1956), pp. 156-162. 
siendo la referencia al lugar escondido o subterráneo el punto de enlace que hace posible la conexión.

\section{ESCRITOS OCULTOS EN LA LEYENDA DE RODRIGO Y EN LA MAGIA TALISMÁNICA}

La articulación de estos dos aspectos tiene orígenes antiguos y lejanos como apuntaré después. Lo que aquí quiero destacar es que se halla profundamente arraigado en un complejo credencial peninsular del que forman parte -además de los aportes clásicos y cristianos- numerosos elementos de procedencia oriental, árabe y judía.

4.1. Notemos primero que en nuestro corpus narrativo y apócrifo asoma repetidas veces la referencia a la leyenda del rey Rodrigo y de la "pérdida de España", verdadero mito nacional y policultural en el que se cruzaron varias tradiciones de origen oriental.

He mencionado el episodio del Amadis de Grecia en el que Feliciano de Silva imagina que encontró el manuscrito que corresponde a la segunda parte de las aventuras de su héroe en "los Palacios de Hércules", donde fue ocultado "quando España fue perdida". Se trata por supuesto de una transformación del mito de la "Casa cerrada" de Toledo imprudentemente abierta por el último rey godo, con las consabidas consecuencias, y de la leyenda local de la "Cueva de Hércules" con la que dicho mito no tardó en contaminarse ${ }^{16}$.

También es de notar que el caso de los apócrifos del Sacromonte nació en 1594 con la aventura de dos buscadores de tesoros, Sebastián López y Francisco García, y que los dos compadres poseían un librito adquirido en 1568 por un capitán sevillano cautivo de los Moriscos: en este folleto se aludía a una antigua mina de oro que pertenecía al rey Don Rodrigo y que, cuando se perdió España, fue cegada por los mineros para que sus riquezas no cayeran en poder de los Moros ${ }^{17}$.

Se sabe por otra parte que Miguel de Luna, uno de los probables artífices de los apócrifos granadinos, fue también autor de una fabulosa historia del rey Rodrigo (1589), en la que recurre, como Cervantes, al truco de la seudo-atribución. En este caso, al supuesto Abulcácim Tárif, presen-

16 Fernando Ruiz de la Puerta, La Cueva de Hércules y El Palacio encantado de Toledo (Madrid: Editora Nacional, 1977).

17 C. Alonso, Los apócrifos..., p. 58 (La noticia se encuentra en la Historia Eclesiástica de Granada de F. Bermúdez de Pedraza). Véase también Miguel José HaGerTY, Los Libros Plúmbeos del Sacromonte (Madrid: Editora Nacional, 1980), pp. 29 y ss. 
tado como contemporáneo de los acontecimientos narrados y depositario de los archivos del rey Rodrigo ${ }^{18}$. Además, transforma en cueva encantada la Casa Cerrada de Toledo, convirtiéndose en viaje subterráneo el clásico episodio de la transgresión por Rodrigo del tabú que prohibía el acceso a dicho edificio ${ }^{19}$ : aparte de las acostumbradas y fatales inscripciones proféticas, el rey godo encuentra en esta cueva una alegoría del Tiempo, figurado por una estatua de bronce que da tremendos golpes con una maza guerrera. Toda esta maquinaria constituye un artilugio mágico, una "espantable visión". Algo similar, en definitiva, aunque en clave desastrosa, a las fantasmáticas revelaciones subterráneas conseguidas por Montalvo en el Esplandián o por el autor ficticio de la Tercera parte del Espejo de príncipes y caballeros en la cueva de Sifronio. En este contexto, la interpretación por una junta de hombres sabios de las inscripciones proféticas que acompañaban la estatua desempeña el mismo papel que la traducción del manuscrito recibido en sendas cuevas por los mencionados autores de ficciones caballerescas.

No nos extrañaremos, por lo tanto, al constatar que fue en la Crónica Sarracina de Pedro del Corral (siglo XV) —otra fabulosa reinterpretación de la leyenda del rey Rodrigo- donde por primera vez se usó de modo intenso el truco de la seudo-traducción y de la referencia a autores imaginarios y manuscritos encontrados en lugares ocultos ${ }^{20}$. Pedro del Corral, cuya obra -igual que la de Miguel de Luna- es a la vez novela de caballerías y falso cronicón, finge en efecto no ser más que el editor de un manuscrito antiguo encontrado hace poco en la tienda de un mercader: afirma que los autores originales de las distintas partes de su crónica son los hermanos Alanzuri y Eleastras, vasallos de Rodrigo, así como un tal Carestes, contemporáneo de Alfonso el Católico. Este Carestes descubrió, según Pedro del Corral, la sepultura oculta de Rodrigo en Viseo, con la debida inscripción, y sobre todo se hizo con el "libro de pergamino" que yacía en la misma tumba, en el que halló la relación de la penitencia y muerte del vencido monarca godo ${ }^{21}$. No dejó tampoco Pedro del

18 Véase Francisco MárQuez Villanueva, "La voluntad de Leyenda de Miguel de Luna", Nueva Revista de Filología Hispánica, 30 (1981), pp. 359-395.

19 Miguel de LunA, La verdadera bistoria del rey Don Rodrigo (Granada, 1592), cap. 6.

20 Véase la edición parcial de la Crónica Sarracina en R. MENÉndez PIDAL, Floresta de Leyendas Heroicas Españolas. Rodrigo el último godo (Madrid: Espasa Calpe, 1973), t. 1 (en particular pp. XCVIII y 94).

${ }^{21}$ Ibid., p. 140. Véase Gloria Álvarez-Hesse, La Crónica Sarracina. Estudio de los elementos novelescos y caballerescos (Nueva York: Peter Lang 1990), pp. 143-150 ("Las autoridades narrativas $)$. 
Corral de contar a su manera el episodio de la Casa Cerrada, en la que, entre otras múltiples inscripciones y profecías, el arrogante rey descubre una gigantesca estatua yacente de Hércules que tiene en la mano un escrito admonitorio: éste, en un atajo narrativo fulgurante, suma el recuerdo de las hazañas del héroe fundador al anuncio de las destruccciones que originará la transgresión apocalíptica del último soberano de los godos ${ }^{22}$.

4.2. El subciclo relativo a la "Casa Cerrada" aparece pues como la encrucijada privilegiada de las múltiples representaciones centradas en el motivo del escrito escondido. En todas las versiones, árabes y cristianas, el prohibido recinto toledano contiene inscripciones o monumentos adornados de inscripciones. Casi todas son proféticas, están acompañadas de representaciones figuradas y anuncian, en combinación con éstas, el futuro desastre causado por la imprudente investigación del rey.

Figuras y escritos tienen, sin embargo, una función más mágica que informativa o documental: a pesar de su aspecto frecuentemente admonitorio (a veces moralizador) desempeñan ante todo el papel de conjuros apotropáicos.

Predomina en este aspecto la tradición talismánica árabe, viva aún en la España morisca, según la cual, para que sea efectivo, un amuleto protector debe llevar símbolos y caracteres escritos y colocarse en un receptáculo cerrado o en algún sitio escondido ${ }^{23}$. Mientras no se abra la Casa Cerrada y no se toquen los objetos que contiene, todo el dispositivo garantiza la seguridad del reino: es a la vez un "tesoro", es decir la reunión de los emblemas de la soberanía (coronas, mesa de Salomón), un cosmograma ${ }^{24}$, y la materialización de un compendio cronístico de la his-

22 R. MEnÉndez Pidal, Floresta..., t. 1, pp. 57-63 (Crónica Sarracina, cap. 30). El mismo detalle de la estatua yacente que tiene una inscripción en su mano se encuentra en la versión de Alfonso Martínez de Toledo (Atalaya de las Crónicas, 1443).

23 Véase el Libro de dichos maravillosos (Miscelánea morisca de magia y adivinación), A Labarta, ed. (Madrid: CSIC, 1993), pp. 0.32-0.36 y pp. 3, 11, 17, 28 y ss., y las múltiples tradiciones árabes relativas a "Balinus" (Apolonio de Tiana): cf. Encyclopédie de l'Islam, 2." ed., s.v. Sobre las raíces antiguas de la magia talismánica se puede leer Christopher A. FARAONE, Talismans and Trojan Horses. Guardian Statues in Ancient Greek Myth and Ritual (Nueva York-Oxford: OUP, 1992).

24 Este aspecto es particularmente relevante en la versión (inspirada por Rasis) de la Crónica de 1344 (cf. F. Ruiz de La Puerta, op. cit., pp. 27-30) en la que se especifica que la Casa de Toledo es redonda y asentada sobre leones de metal; parece una cuba levantada sobre el témpano y contiene un palacio de forma cuadrada, monolítico, desprovisto de maderos y multicolor. Estos elementos, que parecen inspirados en temas cosmogónicos medio-orientales, se volverán a encontrar en la Crónica Sarracina. 
toria peninsular, desde su fundación por Hércules hasta la pronosticada destrucción, pasando por el recordatorio simbólico de la serie de sus reyes. $\mathrm{Y}$ es, por fin y sobre todo, un edificio talismánico con candados, arcas, figuras encerradas, escritos e inscripciones, que contiene y al mismo tiempo neutraliza y sella las fuerzas destructoras ${ }^{25}$.

Reaparece, naturalmente, en este contexto el motivo del libro ocultado, como se puede ver en la versión de Aben Akutiya (que menciona la presencia en la casa de un arca con los cuatro evangelios) o la de Makkari (que se refiere a un pergamino enrollado encerrado en una urna) ${ }^{26}$.

4.3. La estrecha relación de este tópico con la magia talismánica es manifiesta. Es curioso ver cómo tienden a contaminarse y a asumir dimensiones talismánicas o escatológicas los relatos y tipos legendarios que asocian el motivo de la reclusión (en un lugar subterráneo o en un receptáculo escondido) y el tema del poder mágico de la palabra escrita.

Se notará, por ejemplo, que la secuencia narrativa recurrente del manuscrito encontrado en una cueva o sepultura en manos de una efigie yacente o sentada, que puede ser fantasma, estatua o cadáver ${ }^{27}$ (secuencia frecuentemente asociada, como vimos, a un contexto de revelación onírica o de visión para-mística), se entrecruza con el ciclo hagiográfico y escatológico de los Siete Durmientes: así los caballeros sentados en sillas de oro vistos por Montalvo en el transcurso de su periplo subterráneo y visionario que culminará con su acceso al libro de Elisabat, se encuentran esperando el regreso milenarista del rey Arturo; igual que el

25 Véase en particular la versión del Victorial (F. Ruiz de la Puerta, op. cit., pp. 34 y ss.) en la que el rey encuentra en la Casa Cerrada un arca con tres redomas, que contienen respectivamente una cabeza humana, una serpiente y una langosta.

26 F. RUiz DE la PuerTa, op. cit., p. 23. La asociación del tópico del libro escondido con el ciclo de la Casa Cerrada puede explicar en parte que este ciclo se haya contaminado - mediante la transformación de la Casa en Cueva de Hércules- con el tema de las escuelas mágicas de Toledo (subterráneas, como se ve en el cuento de Don Yllán y el Deán de Santiago en El Conde Lucanor, ex. 11). Véase S. WAXMAN, "Chapters on magic in Spanish Literature", Revue Hispanique, 38 (1916), pp. 325-342. Recordemos también que el complejo temático Libro - Cueva - Saber Oculto ya aparece estrechamente vinculado a Toledo en la leyenda del rey Rocas en la Primera Crónica General (cap. 11 y 12) cuya procedencia judía me parece muy probable.

27 Véanse las dos ocurrencias de este motivo en la Crónica Sarracina mencionadas más arriba. Aparece sentada la figura de Elisabat en el episodio onírico de Las Sergas de Esplandián y yacente la de Montesinos en el Quijote. Es motivo antiquísimo, de probable procedencia egipcia (véase notas 63 y 75), difundido en gran cantidad de textos y tradiciones helenísticas, latinas y medievales (árabes, judías y cristianas). 
yacente Durandarte y su amada Belerma en la Cueva de Montesinos, se hallan "encantados", es decir suspendidos fuera del tiempo ${ }^{28}$, en un estado parecido al de los Siete Durmientes, en cuya cueva el fluir del tiempo también tiene ritmo específico ${ }^{29}$. Aunque el despertar de los Durmientes no coincide con el descubrimiento de un libro oculto, es interesante observar que en la tradición árabe se les suele llamar "compañeros de la cueva y de la tablilla", a causa de la tabla de metal (en determinados casos se especifica que se trata de placas de plomo) encerrada con ellos en la cueva, en la que se indican sus nombres junto al motivo y fecha de su reclusión ${ }^{30}$. Ahora bien, estos nombres de los Siete Durmientes, confundidos con los nombres de los genios y demonios conjurados por Salomón, son la base de una serie de amuletos, talismanes y sortilegios moriscos: si se escriben sobre soportes adecuados y en determinadas condiciones, se transforman en conjuros eficaces como el de los "siete omenajes" o el de los "nombres encerrados" ${ }^{31}$. Puesto que los escritos de tipo talismánico se suelen esconder (por ejemplo en un canuto de plata) ${ }^{32}$, se supone que todo escrito escondido tiene valor talismánico y que todas las fórmulas que tienen un poder mágico eficaz, como las del Corán, deben a la fuerza proceder de algún texto escrito más o menos oculto

28 Nótese que en el episodio visionario del Esplandián se indica que antes de volver a la superficie-realidad Montalvo es presa en la cueva de un sueño profundo (sueño dentro del sueño ya que toda la aventura fue soñada) al poner su mano derecha sobre un libro muy pequeño (ed. cit., p. 501) ¿ Se tratará de una reminiscencia del minúsculo librito mágico de Virgilio mencionado en algunas versiones medievales de la novela de los Siete Sabios de Roma (Dolopathos)?

29 J. Filgueira Valverde, Tiempo y Gozo Eterno en la narrativa medieval (Vigo: Ed. Xerais de Galicia, 1982). Véase François Jourdan, La tradition des Sept Dormants, une rencontre entre Chrétiens et Musulmans (Paris: Maisonneuve et Larose, 1983) (con bibliografía). Compárese con Miguel Asín PalaCios, La escatología musulmana en la Divina Comedia (Madrid: Hiperión, 1984), 4." ed., pp. 329-336 ("Leyendas de durmientes").

30 F. JOURDAN, op. cit., pp. 16, 63, 68, 82, 88. También cabe reparar que en la versión atribuida a Ibn' Abbâs el reconocimiento de la identidad del durmiente «resucitado" que se presenta en la ciudad se hace mediante un libro hebreo envuelto en un paño carmesí y encerrado en una caja de oro (F. Jourdan, op. cit., p. 30).

31 Libro de dichos maravillosos, pp. 44-46. Véase A. LABARTA, "Los nombres de los Siete Durmientes en aplicaciones mágicas: un testimonio aljamiado", Homenaje a $A$. Galmés de Fuentes (Oviedo-Madrid, 1985), t. 1, pp. 657-663. Compárese con J. AlBarracín NAVARro y J. MARTínez RUIZ, Medicina, farmacopea y magia en el Misceláneo de Salomón" (Granada: Univ. de Granada, 1987). Sobre el uso mágico de las placas y tablillas se puede ver W. BrasheAR, "A propos des tablettes magiques", Les tablettes à écrire de l'Antiquité à l'époque moderne, E. Lalou ed. (Turnhout: Brepols, 1992) (Bibliologia XII), pp. 149-158.

32 Libro de dicbos maravillosos, p. 51. 
y antiquísimo, o de una inscripción cuyo descubrimiento cobra la dimensión de una revelación ${ }^{33}$.

Vemos por lo tanto que el tema del descubrimiento de antiguos escritos escondidos en lugares cerrados (receptáculo, templo, cueva, palacio, tumba etc.) tiene profundas raíces en las más antiguas tradiciones peninsulares: la fervorosa preocupación textualista estimulada por el Renacimiento no hizo más que revitalizar y resemantizar esta corriente de representaciones latentes, que de modo privilegiado había cristalizado sobre el ciclo fundacional-escatológico de la prehistoria mítica (la gesta heráclea) y de la "pérdida" de España (el desastre gótico), términos iniciales y finales entre los cuales se situaba preferentemente la edad de transición y heroismo de los caballeros andantes, repleta de nostalgias originarias y de presentimientos milenaristas. Vemos también que, como en el caso de los buscadores de tesoros (que tienen que encontrar y luego desencantar el tesoro que codician), el aspecto propiamente arqueológico del tópico del libro escondido alterna a menudo, aunque enlazándose más o menos estrechamente con ellos, con elementos mágico-talismánicos por una parte, y místico-visionarios por otra, a veces reunidos en una común perspectiva escatológica.

\section{LIBROS OCULTOS Y REVELACIÓN}

Esta tendencia mistagógica se nota sobre todo, como es natural, en las adaptaciones ocasionales que se ha hecho de nuestro tópico en la literatura religiosa.

5.1. Si el motivo del descubrimiento de un escrito antiguo u oculto no parece ser más que un lugar común prologal en la literatura hagiográfica ${ }^{34}$, resulta que fue cobrando mayor relieve en las producciones apócrifas ${ }^{35} \mathrm{y}$ en determinadas tradiciones, como la del supuesto ha-

33 Este es el caso de la serie de fórmulas coránicas adicionadas en el "Talismán para cuando querrás pelear" (Ibid., pp. 52 y ss.), curiosamente atribuidas a los "politeístas", cuyos lejanos antepasados encontraron estas palabras escritas con letra antigua sobre las piedras de una iglesia" mil setecientos años antes de la venida del Profeta...

34 A. J. Festugière, "Lieux communs littéraires et thèmes de folklore dans l'Hagiographie primitive", Wiener Studien, 73 (1960), pp. 123-152 (véanse las páginas 124-126, „Découverte d'un vieil écrit").

35 Sobre el Apócrifo de Zacarias y la historia de su edescubrimiento", véase la Historia Eclesiästica de Sozomeno (IX, 17) y Wolfgang SPEYER, Bücberfunde in der Glaubenswerbung der Antike (Göttingen: Vandenhoeck-Ruprecht, 1970), pp. 85-88. 
llazgo del manuscrito autógrafo del Evangelio de San Mateo en la tumba de San Bernabé ${ }^{36}$.

Pero es en la literatura de visiones y revelaciones donde se desarrolla plenamente lo que ya no es un mero tópico sino un verdadero mitema: es harto conocida la interpretación escatológica (antaño atribuida a Joachim de Fiore) del Oráculo de Cirilo el Carmelita, quien recibió de un ángel una serie de profecías grabadas en unas tablas de plata que, según la leyenda, le fueron comunicadas a Joachim por el monje Telésforo ${ }^{37}$.

$\mathrm{Si}$ en este caso, que se relaciona con la tradición de los "escritos caídos del Cielon ${ }^{38}$ y parece haber servido hasta de modelo al mito mormón de las placas de oro reveladas a Joseph Smith ${ }^{39}$, el escrito revelado no es de procedencia subterránea, sino más bien celestial, la leyenda seudoepigráfica de la Revelación de San Pablo entra de lleno en el ciclo temático que nos ocupa. Se sabe en efecto que en este texto, que forma parte del ciclo de la Visio Sancti Pauli, del que existen múltiples versiones en varios idiomas ${ }^{40}$, se cuenta que a un senador romano de religión cristiana se le apareció en sueños el ángel Gabriel para revelarle que, enterrado debajo del suelo de su casa, se encontraba, en un arca de mármol, adornada de inscripciones hebráicas, el tesoro de los escritos de San Pablo. En alguno de estos libros que el mismo Pablo había escondido en ese lugar antes de su martirio, el santo explicaba los misterios que le habían sido revelados durante su visión extática y describía el Más Allá. Encerradas con los libros se encontraron reliquias milagrosas y, cuando se exhumó el arca, un ángel en forma de niño vino a sentarse sobre ella y entregó la llave que permitía abrirla. Existen varias ediciones de la versión española de esta Revelación (Sevilla, 1494; Toledo, 1525; traducción valenciana en 1495) y François Secret ha demostrado la relación de este apócrifo con una serie de ficciones y textos propios de la Cábala Cristiana a partir del final del siglo $\mathrm{Xv}^{41}$.

$36 \quad$ Ibid., pp. $81-85$.

37 Ibid., p. 15, n. 1. Véase en K. BurdaCH, P. PIUR, Briefwechsel des Cola di Rienzo, K. BURDACH (ed.), Vom Mittelalter zur Reformation (Berlín, 1912), II, 4, la edición del Oraculum angelicum Cyrilli, pp. 223-343 (pp. 244 y ss.).

38 W. SPEYER, op. cit., pp. 23-42 ("Bücher vom Himmel").

39 D. M. QuinN, Early Mormonism and the magic world view (Salt Lake City, 1987).

40 W. SPEYER, op. cit., pp. 60-65. Véase la traducción inglesa de J. K. ELLIOTT, The Apocryphal New Testament (Oxford: Clarendon Press, 1993), pp. 616-644 (pp. 620 y ss.) y consúltese el estudio de T. SIlverstein, Visio Sancti Pauli: the bistory of the Apocalypse in latin together with nine texts (Londres, 1935), pp. 20 y ss.

41 François SECRET, "La Revelación de San Pablo", Sefarad, 28 (1968), pp. 45-67. Véase igualmente, del mismo autor, "L'Ensis Pauli de Paulus de Herędia", Sefarad, 26 
5.2. En esta literatura teológica y fantástica a la vez, inspirada en la Cábala judía y tan en boga en determinados medios intelectuales de los Cristianos Nuevos, las especulaciones abstractas sobre el Nombre Secreto de Dios, el valor numérico de las letras del alfabeto y las profecías o revelaciones escondidas en la materia textual de los Libros canónicos van enlazadas con segmentos narrativos de tipo legendario. Estos elementos narrativos de procedencia talmúdica o cabalística asocian revelación espiritual y descubrimiento de escritos ocultos, como se nota en el Ensis Pauli de Paulus de Heredia ${ }^{42}$, en la profecía de San Cataldo ${ }^{43}$, o en el apócrifo sibilino comentado por Tycho Brahe y descubierto, según se decía, en los Alpes después de una avalancha ${ }^{44}$.

En toda esta literatura se postula que el saber esencial sólo puede ser un saber oculto, reservado a iniciados; y que este saber oculto, además de necesitar un desciframiento, tiene que estar cifrado en inscripciones o libros escondidos cuyo descubrimiento viene a ser como la proyección simbólica, en clave arqueológica, de la revelación extática de la que procede este saber. El descubrimiento, por lo tanto, no puede ser realmente casual. Lo determina un sueño o una visión, es decir una experiencia mística de grado menor, por la que el descubridor y futuro difusor del saber oculto se identifica parcialmente con el productor original de este saber. También simboliza el ocultamiento del soporte escrito de este saber - encerrado en una cueva, montaña, o mansión escondida- la condición germinal y mistagógica que éste entraña. No han dejado los exégetas de los apócrifos granadinos de notar las analogías entre los temas y conteni-

(1966), pp. 79-102 y 253-271, y Les Kabbalistes Cbrétiens de la Renaissance (Paris: Dunod, 1964) (caps. 1, 2 y 8).

${ }^{42}$ Id., "L'Ensis Pauli ...", pp. 91 y 267-268. (Heredia raconte comment, dans sa longue quête pour connaître le secret du nom tétragramme, au cours d'un rêve, il vit Elie, qui cédant à ses prières lui indiqua l'adresse d'un rabbin dans une localité de Sicile, et comment à son réveil il se mit en route et trouva enfin l'explication du secret tant recherché, dans le petit livre que lui donna un certain Rabbi Abraham Papur"). El cuentecillo se adhiere en parte al esquema tradicional del "viaje sapiencial": véase Marta HARO, "El viaje sapiencial en la prosa didáctica castellana de la Edad Media", A. Deyermond, R. Penny (eds.), Actas del I Congreso Anglo-Hispano, 2, Literatura (Madrid: Castalia, 1993), pp. 59-72. Se notará que en la Visión Deleitable del converso Alfonso de la Torre el viaje sapiencial incluye la ascensión de un "monte sagrado" simbólico, y que en varios casos el viaje concluye con el descubrimiento o la composición de un libro.

43 F. SECRET, "La revelación de San Pablo", p. 51; W. SPEYER, op. cit., p. 104. Ambos notan la analogía con el caso de los apócrifos granadinos.

44 F. SECRET, "La revelación...", p. 56. 
dos légendarios de esta literatura cristiana neo-cabalística y la escenografía montada por los falsificadores andaluces ${ }^{45}$.

5.3. En tradiciones literarias y folklóricas de signo más profano, aunque no menos fantástico (ya que se trata de leyendas relativas a magos y hechiceros), vuelve a plantearse el motivo del descubrimiento de libros escondidos. Pero se merece este ciclo un estudio detenido: lo reservo para otro ensayo, y me contentaré aquí con observar que en estas leyendas - referidas a Pitágoras, Apolonio de Tiana, Virgilio, etc.- el mencionado tópico entra a formar parte del proceso legendario de adquisición de los poderes mágicos ${ }^{46}$ y se contamina con el tema específico del alibro diabólico" ${ }^{47}$.

\section{MODELOS}

6.1. Cuando los filólogos e historiadores de la literatura intentan explicar la importancia del motivo que estoy comentando en la literatura

45 Véase el libro algo prolijo y florido de Ignacio GÓMEZ DE LiAÑo, Los Juegos del Sacromonte (Madrid: Editora Nacional, 1975), cuyas mejores páginas (pp. 207-212) se lo deben todo a las investigaciones de François Secret (cf. supra n. 43): apunta el autor que varios motivos de la Revelación de San Pablo - luces, olores celestiales, letras hebraicas - son "temas típicos de la invención de los Plomos" y concluye acertadamente que "el Caso de los Plomos fue la ejecución material -0 , mejor, teatralde unos modos que en La Revelación de Sant Pablo no pasaron de ser mera ficción y composición literaria. Los Plomos fue la puesta en obra de este tema del "libro oculto", del escondido tesoro de palabras" (p. 210). Otra prefiguración de los apócrifos de Granada se puede encontrar en la leyenda del judío toledano que en la época de Fernando III se convirtió después de haber encontrado en su viñedo, escondido en el hueco de una piedra, un antiguo manuscrito profético "de triplici mundo" en el que se comentaban "ab Abrabam usque ad Antichristum" las edades de la historia humana: Rodrigo SÁNCHEZ DE ARÉVAlO, Compendiosa bistoria bispanica (Roma, 1468), III, 40: lo saca de Martinus Cusentinus: véase W. SPEYER, op. cit., pp. 42 y ss.

46 E. M. ButLer, The Myth of the Magus (Cambridge: Cambridge University Press, 1980), 2." ed., passim.

47 Id., Ritual Magic (Cambridge: Cambridge University Press, 1949). También se puede consultar Richard KIECKHEFER, Magic in the Middle Ages (Cambridge: Cambridge University Press, 1989), pp. 140-144, 151-157 y passim. Todavía se leen con interés Montague SuMmERS, Witchcraft and Black Magic (Londres: Senate, 1995), 2." ed., cap. 5, y Claude Seignolle, Les Evangiles du Diable (Paris: Maisonneuve et Larose, 1923), 2." ed., pp. 308-334. Véase por fin W. SPEYER, «Das Buch als magisch - religiöser Kraftträger im griechischen und römischen Altertum", P. GANZ (ed.), Das Buch als magisches und als Repräsentationsobjekt (Wiesbaden, 1992), pp. 59-86. 
española del Renacimiento y del Siglo de Oro, suelen referirse a la influencia de los famosos apócrifos de la antigüedad tardía atribuidos a Dictys y a Dares, supuestos narradores de una historia troyana que durante siglos se ha creído mucho más verídica que los poemas homéricos, porque se suponía que sus autores eran soldados que habían participado en la guerra de Troya ${ }^{48}$.

El diario bélico de Dictys, redactado en caracteres fenicios, grabado en tablillas de tilo, encerrado en una caja, ocultado en su tumba y encontrado por pastores después de un terremoto durante el reinado de Nerón, tuvo en efecto enorme fama en la Edad Media ${ }^{49}$, y vino a ser como un modelo para toda clase de falsificaciones literarias ${ }^{50}$, entre ellas la del seudo-ovidiano De Vetula ${ }^{51}$, y para leyendas referidas a manuscritos encontrados en los sepulcros de sus autores o en los muros de sus casas ${ }^{52}$.

Pero dista mucho el relato prologal de la obra de "Dictys" de ser la única versión antigua de este tipo de cuento, que se encuentra en varias tradiciones relativas a las sepulturas de filósofos, reyes o magos transmitidas a lo largo de toda la Edad Media o reactivadas en el Renacimiento ${ }^{53}$.

48 H. ThOMAS, op. cit., p. 13, n. 1; D. EISENBERG, op. cit., p. 124, n. 18; M. C. Marín PINA, op. cit., p. 542, n. 4 .

49 A. JOLY, Benoît de Sainte-More et le Roman de Troie, ou les métamorphoses d'Homère et de l'épopée gréco-latine au Moyen-Age (Paris, 1870), pp. 196-203. Véase A. REY y A. GARCía SOlALINDE, Ensayo de una bibliografia de las leyendas troyanas en la literatura española (Bloomington, 1942), pp. 9, 22, 28, 33, 90. Sobre Dictys y Dares (y sus traducciones) se pueden consultar R. M. Frazer, The Trojan War. The Chronicles of Dictys of Crete and Dares the Phrygian (Bloomington-Londres: Indiana University Press, 1966), y N. E. GRIFFIn, Dares and Dictys. An introduction to the study of medieval versions of the Story of Troy (Baltimore, 1907).

50 Wolfgang SPEYER, Die literarische Fälscbung im Heidniscben und Cbristlischen Altertum (Munich, 1971), pp. 65-79. Consúltense también Anthony GrafTON, Faussaires et Critiques. Créativité et duplicité chez les érudits occidentaux (Paris: Les Belles Lettres, 1993), y Julio CARO BAROJA, Las falsificaciones de la Historia (en relación con la de España) (Barcelona: Seix Barral, 1992), que completa útilmente el libro clásico de José Godoy AlCÁnTARA, Historia Crítica de los Falsos Cronicones (Madrid: Tres Catorce Diecisiete, 1981), 2." ed.

51 Véase Paul KLOPSCH, Pseudo-Ovidius De Vetula. Untersuchungen und Text (Leyde: Brill, 1967), pp. 22-34 ("Das Buch im Graben) y D. M. RoBATHAN (ed.), The PseudoOvidian De Vetula (Amsterdam, 1968), pp. 41-43 (texto del Accessus en el cual se encuentra el cuentecillo del descubrimiento).

52 W. SPEYER, Bücherfunde..., cap. II ("Bücher aus Gräbern und aus der Erde"), pp. 43-124.

53 Cf. las leyendas de los libros pitagóricos encontrados en el sepulcro de Numa (A. Delatte, "Les Doctrines Pythagoriciennes des livres de Numan, Bulletin de la Classe 
6.2. Tampoco basta la referencia a Dares y a Dictys, que no son más que autores supuestos de crónicas seudo-históricas, para explicar el hecho de que el tópico del libro descubierto se encuentre casi siempre vinculado a obras y contextos de carácter místico o visionario o a novelas y episodios narrativos onírico-fantásticos. Se nota en efecto que desde la Antigüedad el tema del descubrimiento de escritos ocultos se relaciona preferentemente con producciones propias de la literatura de ficción - utopías y relatos de viajes fabulosos ${ }^{54}$ - y con contenidos ideológicos de tipo mistérico (como el pitagorismo), o profético y oracular (la tradición sibilina) ${ }^{55}$.

En realidad, para comprender el entronque tradicional y los significados complejos del mitema que estoy explorando, es preciso ampliar el panorama y no adherirse exclusivamente a los criterios filológicos puramente retóricos o genéricos de una crítica de las fuentes literarias. También cabe tener en cuenta los trabajos fundamentales de Wolfgang Speyer ${ }^{56}$, del $\mathrm{Pa}$ dre Festugière ${ }^{57}$ y de François Secret ${ }^{58}$ : sus investigaciones revelan que la amplia difusión y recurrencia del motivo del libro ocultado y descubierto se relaciona con el duradero arraigo en la cultura occidental de una corriente subyacente de representaciones "herméticas", vehiculadas de igual modo en medios cristianos, árabes y judíos, por escritos alquímicos, cabalísticos y mágicos, y por tradiciones orales folklóricas. La península

des Lettres de l'Académie Royale de Belgique, 22 (1936), pp. 19-40), de los escritos encerrados en la tumba de Alcmena (J. SchwArTz, "Le tombeau d'Alcmène, Revue Archéologique, 1 (1958) pp. 76-83), de los manuscritos que Aristóteles hizo depositar en su tumba (L. THORNDIKE, A history of Magic and Experimental Science during the first thirteen centuries of our era (Nueva York-Londres: Columbia University Press, 1964), 6." ed., t. 2, pp. 247 ss.) etc.

54 A. CHASSANG, Histoire du Roman et de ses rapports avec l'Histoire dans l'Antiquité grecque et latine (Paris, 1862), pp. 83 y ss., 154, 359, 385. El tema de los escritos ocultos (estelas con inscripciones, manuscritos, tablillas etc.) descubiertos en algún lugar recóndito y utilizados por el autor de algún apócrifo o relato maravilloso se encuentra en la Historia Sagrada de Evemero, en las novelas de viajes fabulosos de Antonio Diógenes y Hecateo de Abdera, en el tratado de Plutarco sobre la cara de la luna (942 C), etc.

55 Jean GAGÉ, Apollon Romain (Paris: E. De Boccard, 1955), pp 24-38, 270-279, 327-338, 432-434, 446-461, 542-555. Cf. supra n. 53.

56 Bucherfunde ... (cf. supra n. 35).

57 A. J. Festugière, La Révélation d'Hermes Trismégiste, I, L'Astrologie et les Sciences Occultes (Paris: Gabalda, 1944), pp. 229-231 y todo el cap. 9 ("Les fictions littéraires du Logos de Révélation"): véanse en particular pp. 319-324 ("Révélation par la découverte d'un livre ou d'une stèlen).

58 Cf. supra n. 41 
ibérica, como encrucijada de culturas y religiones del "Libro" y como crisol de tradiciones gnósticas de procedencia oriental tenía que ser el epicentro de la recopilación, producción y difusión de este tipo de ficciones.

6.3. La génesis de este complejo de representaciones es antiquísima, y parece derivar de la contaminación de un tema mítico-ritual relacionado con la monarquía babilónica y de un conjunto de creencias y relatos folklóricos egipcios referentes a la magia, tanto en sus formas teóricas como en las operativas.

Tal como demostró G. Widengren en un ensayo fundamental, se desarrolló en la cultura mesopotámica una rica mitología relativa a la adquisición por el rey, mediante una ascensión simbólica, de un libro o estela celeste, que le entregan los dioses con motivo (y como condición) de su entronización 59 . Este escrito sobrenatural (tablillas de la Sabiduría") entraña el conocimiento del Destino y de las realidades divinas: es a la vez símbolo e instrumento del poder real, y su entrega se renueva ritualmente en cada fiesta de año nuevo, cuando se echan las suertes del ciclo venidero.

El mismo autor ha puesto de manifiesto la influencia de este complejo mítico inicialmente centrado en la Realeza Sagrada sumeria sobre la religión judía (las tablas de Moisés, la visión de Ezequiel y la iniciación de Enoch) ${ }^{60}$ y sobre las tradiciones gnósticas neo-hebreas, samaritanas, mandaicas e iranias ${ }^{61}$, en las que asoma la idea de Libros divinos y ocultos anteriores a la creación, en los que constan los destinos del universo.

En fin este sistema de ideas e imágenes ha sido integrado y recuperado por el Islam, concretamente en la leyenda de la Ascensión visionaria de Mahoma (durante la cual le fue entregado el Corán), pero también, en las tradiciones islámicas más o menos heterodoxas del Irán y en lo que se ha llamado el "gnosticismo musulmán" ${ }^{62}$ : en estos contextos se

59 Geo WIDENGREN, The Ascension of the Apostle and the Heavenly Book (King and Saviour III) (Leipzig: Uppsala University, 1950).

$60 \quad$ Ibid., pp. 22-39.

61 Ibid., cap. 3 y 4 . Véase también, del mismo G. WIDENGREN, "Holy Book and Holy Tradition in Irann, F. F. BRUCE, E. G. RuPP (eds.), Holy Book and Holy Tradition (Manchester: Manchester University Press, 1968), pp. 36-53.

62 Geo Widengren, Mubammad, the Apostle of God, and bis Ascension (King and Saviour, V) (Wiesbaden: Uppsala University, 1955): véanse en particular las pp. 94 y ss., 96-114 y todo el cap. 6, "The Heavenly Book». La entrega del Corán a Mahoma es el centro de la leyenda visionaria relatada en el Libro della Scala: cf. M. Asín PALACIOS, op. cit.; Le livre de l'Echelle de Mabomet (Paris: Librairie Générale Française, 1991), pp. 234-239 (cap. 49), y E. CERULLI, Nuove Ricerche sul Libro della Scala e la 
plasmó la idea para-cabalística del Libro Celestial, arquetipo eterno e inagotable de todos los libros revelados, que sólo son porciones de Él en forma de pergaminos o tablillas. El acceso a este Libro ideal supone a la vez una experiencia extática de tipo místico, un contacto directo con entes sobrenaturales ${ }^{63}$ y la noción de una cadena de transmisión espiritual en forma de revelación cíclica desde Adán y los Patriarcas, primeros receptores de un Escrito Sagrado de celestial procedencia, hasta el Profeta.

Ahora bien, en el contexto sincrético de la civilización helenística, se fusionó este conjunto de representaciones "gnósticas" de origen oriental con temas mitológicos y folklóricos de procedencia egipcíaca relativos a las inscripciones y libros de magia ocultos en templos, tumbas y pirámides y a la invención de la escritura por un dios o un "héroe civilizador" ${ }^{64}$.

El resultado de esta contaminación es que el libro celestial pase a ser subterráneo y a que se le atribuyan las características de un instrumento de magia operativa: sin embargo, el aspecto iniciático del acceso al libro oculto sigue siendo fundamental, ya que el proceso de adquisición del poder mágico que entraña toma por modelo el esquema de la entronización del rey sagrado sumerio, y se establece una equivalencia simbólica evidente entre ascensión y catabasis ${ }^{65}$. Este proceso iniciático cobró en

conoscenza del Islam in Occidente (Vaticano, 1992), pp. 283, 293 (leyenda del Santo Manuscrito, conservado en un arca, que acompaña la "Luz de Mahoman y se transmite con ella, como Testamento, a todos los antepasados del Profeta). Véase también G. WIDENGREN, "Holy Book and Holy Tradition in Islam", Holy Book and Holy Tradition (cit. supra n. 61), pp. 210-236. Sobre el "gnosticismo musulmán" véase id., The Ascension..., cap. 5 ("Hermetic-gnostic Literature in the Arabic Languagen); Louis MASSIGNON, "Inventaire de la littérature hermétique arabe", A. J. Festugière, La Révélation..., I, appendice III, pp. 384-400, y Ernest BLOCHET, "Études sur le Gnosticisme Musulman", Rivista degli Studi Orientali, 2 (1909), pp. 717-756, 3 (1910), pp. 177-203, 4 (19111912), pp. 47-79 y 267-300, 6 (1913), pp. 5-67. Se pueden consultar, finalmente, los artículos "Hirmis" (Hermes), "Idris" y "Sabi'a" en la Encyclopédie de l'Islam, 2." ed.

63 El motivo del trono o de la cama en que están sentados o yacentes los personajes que entregan los textos ocultos en las novelas de caballerías y tradiciones sobre la pérdida de España (cf. supra n. 27) parecen remitir, tanto como al tema del libro encontrado en una tumba (de probable procedencia egipcia: véase W. SPEYER, Bucherfunde..., pp. 43-59), a la imagen, esencial en la mitología que estoy comentando, del trono celeste cerca del cual se obtiene el Libro de la Revelación (G. WIDENGREN, Mubammad..., pp. 126 y ss.) y al tema central de la entronización del Rey Sagrado en la ideología de la realeza babilónica de la que deriva esta mitología (id., The Ascension..., pp. 7-21).

64 Id., The Ascension..., p. 80. Véase W. SPEYER, Bucherfunde..., pp. 43-51.

65 Fritz Graf, La Magie dans l'Antiquité gréco-romaine (Paris: Les Belles Lettres, 1994), cap. 4. (en particular pp. 107-114). Como apunta G. WIDENGREN, The Ascension..., 
Egipto una dimensión literaria y folklórica, que suministró prototipos narrativos a la cuentística ptolomaica (sobre todo al conocido relato de las aventuras del príncipe Setni-Kaemuas en el que se destaca el agitado episodio de la conquista del libro mágico de Thot en la tumba de Noferkeftah) ${ }^{66}$.

6.4. Aquí se hallan los modelos de una larga y duradera serie de leyendas de filósofos, escritores, magos y profetas que encuentran o roban libros y escritos sagrados en templos, sepulcros, cuevas o ruinas ${ }^{67}$. Este tipo narrativo ha sido ampliamente difundido por la literatura y la tradición oral árabe, donde se entrecruza con el ciclo folklórico de los relatos sobre los monumentos talismánicos provistos de inscripciones: hemos visto cómo ambas corrientes confluyen en el ciclo de la pérdida de España ${ }^{68}$.

También vino a ser este motivo elemento recurrente en la literatura mágico-hermética, desde los más humildes amuletos o papiros mágicos ${ }^{69}$

p. 80. "in this literature descent into the netherworld and ascent to heaven always correspond. Se notará que ambos temas coexisten en el Quijote (episodios de Clavileño y de la Cueva de Montesinos).

${ }_{66}$ Antes de ser conquistado por Noferkeftah, el libro se encontraba enterrado bajo el cauce del Nilo, encerrado en una serie de cofrecillos de metal encajados uno dentro de otro y custodiado por serpientes: véase Textes sacrés et textes profanes de l'ancienne Egypte, 2, Mythes, contes et poésie (Paris: Gallimard, 1987), pp. 190-205 ("Les tribulations magiques de Setni-Khaemouas et de son fils Sa-Ousir", "Première histoire: la quête du Grand Livre de Magien).

67 Filostrato, Vida de Apolonio de Tiana, VIII, 19-20; PLINIO, NH. XXX, 9; véase supra n. 51 a 54, A. J. FESTUGière, La Révélation..., 1, pp. 319-324 y Joseph BIDEZ y Franz Cumont, Les Mages Hellénisés (Paris, 1938), 1. Índice, s.v. "Stèles" y "Temples".

68 Jan KNAPPERT, Islamic Legends (Leiden: Brill, 1985), 1, p. 4. Léase Jamel Eddine BENCHEIKH, Les Mille Et Une Nuits ou la parole prisonnière (Paris: Gallimard, 1988), pp. 165-166; René BASSET, Mille et un contes, récits et légendes arabes (Paris, 19251927), 1, pp. 224 y ss., 234, 238 y ss., 240 y ss., y CARRA DE VAuX, L'Abrégé des Merveilles (Paris, 1898), passim (sobre todo en la segunda parte, dedicada a las maravillas de Egipto). Se usará con provecho la Bibliographie des ouvrages arabes de Victor Chauvin (12 vol.) (Lieja, 1892-1922), 5, pp. 39-41 (La mezquita de Theïloun), pp. 142 y ss. (leyenda de Avicena), pp. 257-272 ("Djaudar"), 6, pp. 84-89 (Maugraby le Magicien) y 7, pp. 106 y ss. ("Chahabeddin"). En estos cuentos se encontrarán los elementos que entrarán a formar parte de las leyendas relativas a la conquista de España (ciclo de la "Ciudad de (obre"), a las cuevas, escuelas de magia y bibliotecas subterráneas de Toledo y Salamanca, y a las inscripciones y monumentos talismánicos de la península.

69 William BrasheAR, "Magical Papyri: Magic in Bookform", Das Buch als magisches.. (cf. supra n. 47), pp. 25-57, en particular pp. 26-30; André BERNAND, Sorciers Grecs (Paris: Fayard, 1991), pp. 23 y ss., 55 y ss. 
hasta los más conocidos tratados de alquimia ${ }^{70}$. La fusión sincrética entre la gesta de Thot, dios egipcio de la magia y de la escritura, de la que se supone que fue el inventor ${ }^{71}$, con la figura griega de Hermes y con tipos legendarios orientales (babilónicos y fenicios) relacionados con escritos ocultos ${ }^{72}$ permitió plasmar el mito de Hermes Trismegisto ${ }^{73}$ que, vinculado a leyendas referentes al origen de la escritura, y conectado con personajes más o menos análogos como Seth, Enoch o su equivalente árabe Idris, cruzó los siglos y conoció en el Renacimiento, como se sabe, una boga extraordinaria ${ }^{74}$.

Desempeñó además un importante papel en la fijación y difusión del motivo novelesco del libro hermético encontrado en algún recinto funerario o sagrado el marco narrativo en el que está engastada la version árabe de la famosa Tabula Smaragdina ${ }^{75}$, tantas veces imitado en las literaturas mediterráneas a lo largo de la Edad Media ${ }^{76}$, en el que se cuenta

70 A. J. Festugrère, La Révélation..., 1, pp. 320-322; M. Berthelot, la Chimie au Moyen-Age (Paris, 1893), 2, pp. 309-312 ("Lettres de Pébéchius"), 3, pp. 119-123 ("Extrait du Livre du Sage Ostanès") y 44-75 ("Le Livre de Cratès").

71 Patrick Boylan, Thot. The Hermes of Egypt (Oxford: Oxford University Press, 1922), cap. 10 y 11.

72 Sergio RiBichinI, "Taautos et l'invention de l'écriture chez Philon de Byblos", Phoinikeia Grammata (Namur, 1991), pp. 201-213 (con la bibliografía anterior). Véase M. R. LIDA DE MALKIEL, "Las infancias de Moisés y otros tres estudios", Romance Philology, 23 (1970), pp. 412-448, en particular pp. 424-432 ("Los pilares de la Sabiduría").

73 A. J. Festugière, La Révélation..., passim.

74 Frances YATES, Giordano Bruno and the Hermetic Tradition (Londres: Routledge and Kegan, 1964). Sobre la continuidad árabe de la tradición hermética, véase A. E. AfFIFI, "The influence of Hermetic Literature on Moslem Thought", Bulletin of the School of Oriental and African Studies, 13, 4 (1951), pp. 840-855 y M. Plessner, "Hermes Trismegistus and Arab Sciencen, Studia Islamica, 2 (1954), pp. 45-59. Cf. supra n. 62.

75 Véanse G. WIDENGREN, The Ascension..., pp. 77-85, J. RUSKA, Tabula Smaragdina. Ein Beitrag zur geschichte der Hermetischen Literatur (Heidelberg, 1926), pp. 61-68 y 112-114 y la edición reciente de La Table d'Emeraude et sa tradition alchimique (Paris: Les Belles Lettres, 1994). En el prólogo del Libro del Secreto de la Creación, texto árabe en el que se reproduce la Tabula, Balinus (Apolonio) cuenta que penetró en el cuarto funerario del sepulcro de Hermes Trismegisto, encontró en él a un anciano (el mismo Hermes), sentado en un trono de oro, que tenía en sus manos la referida Tabula y un libro de los secretos y causas universales, y se apoderó de dichos escritos (de los que se supone que sacará la materia de su propio libro). La analogía de los episodios caballerescos mencionados arriba con este tipo de escena es mayor que la que tienen con la fábula prologal de Dictys...

76 L. THORNDike, op. cit., 2, cap. 45, "Hermetic books in the Middle Ages" (en particular pp. 216 y ss., 224 y ss., 230, 233). Sobre las traducciones latinas y múltiples adaptaciones de la Tabla de Esmeralda en las literaturas medievales y modernas 
cómo Apolonio se apoderó, en la tumba de Hermes Trismegisto, del libro del saber de todas las cosas y causas ocultas.

\section{El PAPEL DE LA CONEXIÓN HEBREA}

7.1. La pujanza de este mitema, inicialmente indisociable del concepto de "Logos de Revelación", fue tal que contagió a toda clase de escritos apócrifos, a veces totalmente desprovistos de trasfondo sagrado o místico, como fueron los ya mencionados cronicones de Dictys y Dares ${ }^{77}$. El éxito de éstos contribuyó, como vimos, a difundir el tópico, pero en muchos de los textos medievales y auriseculares que he mencionado aparecen elementos que la influencia de dichos cronicones no puede explicar y que en cambio parecen referir, directa o indirectamente, al repertorio imaginario y narrativo de la tradición hermética. Es el caso, en particular, de la ficción de la entrega del escrito oculto en un recinto subterráneo al nuevo "autor" por una figura de cariz más o menos sobrenatural, mantenida en el limbo de un más allá del tiempo y de la realidad objetiva. Este "narrema" que asoma, como vimos, varias veces en novelas de caballerías y en relatos apócrifos de visiones se vincula frecuentemente con un contexto onírico y con un repertorio imaginario para-místico. Tanto se parece al argumento narrativo mediante el cual se introducen la Tabula Smaragdina o novelas herméticas hechas sobre el mismo modelo, que casi nos obligaría a suponer que dichas obras tuvieron una difusión e influencia mucho mayores de lo que generalmente se supone. Aunque sí hay que tener en cuenta el hecho de que la influencia del neoplatonismo renacentista pudo mantener vivos y difundir modelos formales e ideológicos de tipo hermético, me parece más importante notar que, en el caso particular de la península ibérica, y del motivo narrativo que estoy comentando, ciertas tradiciones judías - antiguas y medievales, generales y locales, ortodoxas y gnósticas- pudieron determinar, no sólo en ambientes hebreos, sino también conversos, moriscos y cristianos nuevos, la

véase la bibliografía mencionada en la introducción de La Table d'Emeraude et sa tradition alchimique por Didier Kahn (p. IX-XXVII)

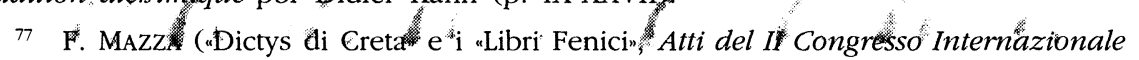
di Studi Fenicine Punici Roma, 1987], Roma, 1991, 1, pp. 155-160) pone de relieve las analogîas entre Dictys y el Sanchuniathón de Filơn de Bißtos e indicá que representan un intento de "recupero delle tradizioni e dei valori delle civiltá vicino-orientali [...] rivendicandone l'antichitá e le prioritá nelle scoperte e nelle conquiste del sapere, in polemica contrapposizione con la predominante visione ellenocentrica e con il livellamento operato dalla forza acculturatrice della civiltá greco-romana" (p. 160). 
perpetuación o la reactivación del sistema de representación dentro del cual se inserta dicho motivo.

7.2. Al no poder dedicar aquí a este asunto todo el espacio que se merece, me contentaré con apuntar esquemáticamente algunos elementos de procedencia judía entre los que pudieron contribuir a promover en las culturas ibéricas el tipo narrativo del descubrimiento de escritos ocultos.

7.2.1. Notemos, en primer lugar, que dicho motivo se relaciona desde la antigüedad con la figura de Salomón: en las tradiciones rabínicas y árabes se supone que Salomón fué un gran mago que reunió gran cantidad de libros de magia que hizo encerrar debajo de su trono. Después de su muerte serían encontrados por los demonios, que los divulgaron entre todo el pueblo judío ${ }^{78}$. Esta leyenda, destinada a explicar el origen y la conservación de tantos libros de magia entre los judíos, fue recogida y desarrollada en la Edad Media: viene a confluir con la leyenda rabínica del dominio de Salomón sobre los demonios, relacionada con la tradición de la magia talismánica ${ }^{79}$ —en la que el "sello de Salomón" desempeña un papel importante ${ }^{80}$ - y con el dispositivo narrativo que servirá de marco a algunas versiones de la famosa Clavicula Salomonis. En estos textos, se supone que dicha Clavicula es el testamento de Salomón y el compendio de su sabiduría más secreta: el rey mandó a su hijo Roboam en el momento de morir que la pusiera en su sepultura dentro de una caja de marfil. La encontraron más tarde unos sabios babilónicos, pero sólo uno de ellos, iluminado por un ángel, consiguió descifrar e interpretar el grimorio ${ }^{81}$. En la Edad Media se contaba con frecuencia que algunos de los mayores filósofos (es decir magos), como Aristóteles, Virgilio o "Toz Graecus" (es decir, el dios Toth, o sea Hermes Trismegisto) debieron su saber al descubrimiento que hicieron del libro oculto de Salomón ${ }^{82}$.

78 P. SAINTYVES, "Salomon. Son pouvoir et ses livres magiques", Revue des Traditions Populaires, 28 (1913), pp. 410-425. Véase G. Widengren, Muhammad..., pp. 147 y ss. y E. M. Butler, The Myth of the Magus, pp. 40-42.

79 Cf. supra n. 31, y Libro de dichos maravillosos, p. 44.

80 J. Leite De VASCONCellos, Etnografia Popular Portuguesa (Lisboa, 1985), 9, pp. 282-292. Véase J. MARQues-Riviere, Amulettes, talismans et pantacles (Paris: Payot, 1972), cap. 1.

81 E. M. Butler, Ritual Magic, pp. 49 y ss., p. 80. Léase The Key of Solomon the King (Clavicula Salomonis), S. L. MacGregor Mathers (ed. y trad.) (Londres: Routledge and Kegan, 1974) (1." ed., 1888), pp. 1-4, y L. THORNDIKE, op. cit., 2, cap. 49 ("Solomon and the Ars Notoria").

82 M. MENÉNDEZ PELAYo, Historia de los Heterodoxos Españoles (Madrid: BAC, 1965), 2. ${ }^{a}$ ed., 1, pp. 591-593, a propósito del Aristóteles mencionado en la apócrifa Virgilii 
Ya se sabe que la Clavicula circuló mucho en España - la mencionan varios pleitos inquisitoriales ${ }^{83}$-, y que las leyendas de los poderes y objetos mágicos de Salomón están íntimamente asociadas a la gesta árabe de Muza y de la conquista de España (ciclo de la "ciudad de cobre" y de la "mesa de Salomón" ${ }^{84}$. No es de extrañar, por consiguiente, que el sello de Salomón aparezca por todas partes en los plomos apócrifos del Sacromonte, y que entre ellos se haya encontrado un comentario narrativo atribuido a San Cecilio sobre la «historia del sello del Profeta de Dios Salomon" ${ }^{85}$.

7.2.2. Se sabe, por otra parte, que las falsas atribuciones, así como la composición y divulgación de apócrifos, son una constante de la antigua literatura hebrea ${ }^{86}$, en la cual aparece desde muy temprano el tema del descubrimiento de libros ocultos: famosa es la leyenda, evocada sucintamente en el Segundo Libro de los Reyes (XXII 8-10, XXIII 1-3), del hallazgo del manuscrito mosaico del Deuteronomio, encontrado en el año 621 por un sacerdote en una pared del Templo de Jerusalén, donde había sido ocultado para ser sustraido a las despiadadas maquinaciones de Achab. Bermúdez de Pedraza no dejó de comparar con este famoso episodio bíblico el descubrimiento de los manuscritos de la granadina Torre Turpiana ${ }^{87}$.

7.2.3. En el caso del Deuteronomio, la fábula del libro oculto encubre una probable mixtificación destinada a conferir antigüedad y pres-

Cordubensis Philosophia. Véase también Ibid., p. 613, n. y J. Caro Baroja, Vidas Mágicas e Inquisición (Madrid: Taurus, 1967), 1, pp. 139-140 (alusión de Juan Bautista Pérez, en un comentario sobre los apócrifos granadinos, a una obra en la que se menciona el descubrimiento por Virgilio de un escrito de Salomón en árabe), y L. THORNDIKE, op. cit., 2, pp. 225-227.

83 J. Caro Baroja, op. cit., 1, pp. 135-151, "El libro mágico (La Clavícula de Salomón)"

${ }^{84}$ Nótese que en las versiones del mito de la "Casa Cerrada" en las que se describe el palacio como un edificio de forma circular contenedor de una sala cuadrada se hace manifiesto que dicho edificio es una especie de pentáculo, el equivalente antitético de la Ká Ba de La Meca (J. MARQues-RIvière, op. cit., pp. 137-140; véase F. RUiz DE LA PuerTa, op. cit., pp. 27-34).

85 Miguel José Hagerty (ed.), Los Libros Plúmbeos..., pp. 285-288. El cuento del castigo y penitencia de Salomón es punto cardinal en la literatura aljamiada.

86 Morton SMITH, "Pseudepigraphy in the israelite literary tradition", Pseudepigrapha I (Vandoeuvres-Ginebra, 1971), pp. 191-215 (véase también la discusión, pp. 216-227).

87 Bermúdez de Pedraza, Antigüedad y excelencias de Granada (Madrid, 1608), p. 151 vo. (se refiere para la anécdota a Nicolas de Lyra, que a su vez remite a uun doctor hebreon). 
tigio a los nuevos valores propugnados por un reducido grupo de reformadores.

Pero en la literatura rabínica posterior y, sobre todo, en la corriente cabalística, el mismo tema adquiere una dimensión mítica y sirve a un propósito hermeneútico y metafísico. En indirecta continuidad con la mitología babilónica, aludida más arriba, del Libro celeste revelado, se difunde en ciertos ambientes judíos más o menos sectarios y heterodoxos la idea de que los escritos sagrados canónicos conocidos no son más que una parte de un Libro prototípico o de una colección de libros de procedencia divina, cuyo contenido principal se ha escamoteado, perdido o alterado.

A unos pocos elegidos queda reservado, mediante una revelación trascendental o un místico trabajo de desciframiento, el acceso a este $U r$-Texto ocultado o disimulado bajo la literalidad de los escritos de que disponemos. Lo mismo que Toth, Hermes o Sanchuniathón en las tradiciones paganas, los patriarcas y profetas bíblicos Esdras, Seth, o Enoch pasan a ser, en algunas tradiciones gnósticas y helenísticas, descubridores de escritos escondidos o beneficiarios de la revelación celeste de un saber oculto del que se harán secretarios, redactores y divulgadores ${ }^{88}$. Leyendas y conceptos de este tipo fueron adaptados y reactualizados en tradiciones proféticas y herméticas musulmanas más o menos ajenas al Corán, en las que se supone por ejemplo que Adán (o Seth, o Enoch) fue depositario de unos escritos esotéricos que le fueron comunicados directamente por el Cielo ${ }^{89}$. De creencias análogas también se hace eco la literatura etiópica en la que cundió (s. XIV) una curiosa tradición relativa a "libros secretos" del Antiguo y Nuevo Testamento que fueron escritos pero nunca divulgados ${ }^{90}$.

7.2.4. Parece ser, sin embargo, que fue en la literatura cabalística occidental y en los libros de magia influidos por ella donde con mayor amplitud y claridad se desarrolló el mitema del Libro Secreto (que es también libro de secretos); y que la península ibérica pudo haber sido privilegiado foco de difusión de estas ideas y creencias ${ }^{91}$. Gran influencia

88 G. WIDENGREN, Mubammad..., pp. 139-142.

89 Ibid., pp. 23-24. Cf. E. Blochet, op. cit., Rivista degli St. Or., 2 (1909), pp. 730 y ss., 738 y ss..

90 E. CERL LI, La Letseraturd Etiopica Florencia-Milano: Sanson/Accademia, 1968), 3." ed.,pp. 42 y ss. Véase también, del mişmo autôr, "La questione del Corano increato "e le dottrine analơghe nel giudarmo e Chistianesimo d'Orienten, Lsslam di teri $e d i$. oggi (Roma: Istituto per l'Oriente, 1971), pp. 59-65.

91 F. SECRET, Les kabbalistes chrétiens..., caps. 1, 2 y 8. Véase G. SCHOlem, Les Origines de la Kabbale (Paris: Aubier-Montaigne, 1966), cap. 4 y, del mismo autor, La Kabbale et sa symbolique (Paris: Payot, 1966), cap. 2, en particular pp. 89-98. 
tuvieron en particular las páginas del Zohar en las que se cuenta, al hilo de un comentario de Génesis $V, 1$, que cuando Adán estaba en el jardín del Edén, Dios le hizo entregar por el ángel Raziel un libro en el que estaban encerrados los setenta y dos tipos de sabiduría. Este libro que Adán estudió, ocultándolo a los Ángeles superiores (porque sólo él tenía derecho a conocer los secretos de Dios), le fue sustraído con motivo del pecado original; pero le fue ulteriormente restituido por el ángel Rafael, y por ello lo pudo transmitir a su hijo Seth y a todos sus descendientes. Gracias a eso pudieron poseerlo Abraham y Enoch ${ }^{92}$. Parece ser que este libro es el mismo que, según otro episodio del Zohar, encontró Rabí Yossi en el fondo de una cueva, engastado en una roca: en él pudo leer las setenta y dos letras reveladas a Adán y una profecía completa de todo lo que había de ocurrir hasta el fin del mundo. Pero a él también le fue sustraído el libro (y el recuerdo de lo que en él había leído) porque no conviene que se divulguen antes de tiempo todos los secretos divinos ${ }^{93}$.

Como era de esperar, un tema análogo recorre el Libro de Raziel que se sitúa en el punto intermedio en que se cruzan las especulaciones cabalísticas (tipo Zohar) y la magia operativa (tipo Clavículas de Salomón $)^{94}$. En esta compilación de elementos diversos por sus contenidos y fechas se inserta el Sepher-Ha-Razim en cuya introducción se indica que dicho tratado le fue entregado a Noé por el ángel Raziel ${ }^{95}$ : el

92 Le Zohar, trad. fr. C. Mopsik (Paris: Verdier, 1981), 1, pp. 282-284 (I.55 b).

93 Ibid., 2, 1984, pp. 150-152 (I,117 b-118 a). Sobre las setenta y dos letras que componen el Nombre Secreto de Dios véase J. E. Fossum, The Name of God and the Angel of the Lord (Tübingen: J.C.B. Mohr, 1985), pp. 251 y ss. y J. TRACHTENBERG, Jewish Magic and Superstition. A study in Folk Religion (Nueva York: Atheneum, 1987) 2." ed., pp. $90-97$ y pp. 289 y ss., n. 30.

94 Véase F. SECRET, "Sur quelques traductions du Sefer Razi'el", Revue des Etudes Juives, 128 (1969), pp. 223-245; id., "La revelación de San Pablo", pp. 55 y ss. La primera edición impresa es la de Amsterdam 1701, pero existen manuscritos renacentistas y algunos componentes del libro son mucho más antiguos. Como muchos manuales de magia (cf. las "Clavículas"), se atribuyó a veces su composición al rey Salomón (L. ThORNDike, op. cit., 2, p. 281). Sobre su uso y fama como libro de magia léase J. Trachtenberg, op. cit., passim (cf. index, s.v. "Raziel").

95 Sepher Ha-Razim. The Book of Mysteries, trad. de M. A. Morgan (California: Scholars Press, 1983), pp. 17-20. Se compuso probablemente en el siglo IV. Véase G. WIDENGREN, Muhammad..., p. 148. El hecho de que en este caso el libro se entregue a Noé y no a Adán parece entrañar alguna analogía con el mito hermético de las estelas de Toth (el primer Hermes) rescatadas por el segundo Hermes después del diluvio (S. RibichinI, op. cit., pp. 208 y ss.; E. BlOCHET, op. cit, Rivista degli St. Or., 2 (1909), pp. 745-748), cuyo tema principal tiene claros antecedentes en la mitología babilónica del diluvio. 
patriarca lo inscribió sobre un zafiro, lo encerró en un receptáculo de oro y se lo llevó consigo en su arca. Después, tras el Diluvio, lo transmitió a sus descendientes, quienes se lo comunicaron de generación en generación, en sucesión ininterrumpida de profetas y patriarcas, hasta el rey Salomón, quien lo recibió y guardó como tesoro de su biblioteca.

Estos mitos gozarían de cierta popularidad en los talleres cronísticos de Alfonso el Sabio: lo pone de manifiesto de modo indirecto la extraña leyenda del rey Rocas, en el capítulo 11 de la Primera Crónica General, en la que se cuenta que este primer poblador de Toledo encontró setenta pilares aen que yazien escriptos todos los saberes e las naturas de las cosas e cuemo savien dobrar, y compuso a partir de ellos un libro que le sirvió para formular profecías y efectuar operaciones mágicas ${ }^{96}$. Podemos suponer por otra parte que el Libro de Raziel formaba parte de la biblioteca mágica del Marqués de Villena ya que su impugnador (y autor de la quema de dicha biblioteca), el obispo Don Lope de Barrientos, lo menciona y vitupera en su Tratado de la divinanza ${ }^{97}$ : en la versión aludida por el mencionado obispo, el reprobado libro sería fruto de la enseñanza mágica otorgada por Raziel a Seth (ya vemos que la leyenda tuvo formas variadas) y tendría especial vigencia en España ${ }^{98}$.

7.2.5. En esta literatura, el tema de la revelación del libro celestial, que sirve de enlace entre metafísica gnóstica, angelología y magia práctica, parece proceder de una proyección imaginaria del concepto básico de la Cábala, en la que se atribuye un poder mágico y generativo a las letras que componen el Nombre Secreto de Dios, y un papel trascendental a una cadena de transmisión reservada, compuesta de una serie ininterrumpida y oculta de sabios que se comunican a través del tiempo una Ciencia esotérica y perenne ${ }^{9}$.

96 Ed. R. MENÉNDEZ PidAl (Madrid: Gredos, 1977) 3." ed., p. 12. Cf. supra n. 26 y M. R. LIDA DE MALKIEL, op. cit., p. 426. Véase F. SECRET, "Sur quelques traductions du Sêfer Razi'el, pp. 233, 245. En esta leyenda se contaminan el tema de las estelas (o pilares) de la sabiduría (cf. leyenda de Toth, Seth etc.) y el mito de la revelación del libro celeste.

97 J. Caro Baroja, op. cit., 1, p. 137. Véase M. MenÉndez Pelayo, op. cit., 1, pp. 621 y ss.

98 "Este libro es más multiplicado en España que en las otras partes del mundo" (citado por M. MenÉndez Pelayo, op. cit., 1., p. 622).

99 Véase de G. SCHOLEM, "Le nom de Dieu ou la théorie du langage dans la Kabbale mystique du Langage", Le Nom et les Symboles de Dieu dans la mystique juive (Paris: Cerf, 1983), pp. 55-99 y, del mismo, "La tradition des trente-six justes cachés", Le Messianisme juif (Paris: Calmann Levy, 1974), pp. 359-365. 
Este libro invisible, sobrenatural y sólo asequible a través de una visión o revelación (claves no sólo de su ubicación sino también de la comprensión de su contenido), no tarda en transformarse, en las versiones folklorizadas del mito, en libro material escondido, redactado en algún idioma antiguo o exótico, descubierto más o menos casualmente en una cueva o en los cimientos del edificio donde se ha ocultado. Existe en efecto en el folklore judío toda una serie de tradiciones orales - creencias, cuentos y leyendas - fundadas sobre este motivo que han hecho posible su difusión a ambientes extra-judáicos y su adaptación en producciones literarias profanas más o menos ajenas a la tradición metafísico-cabalística en la que se generó y funcionó inicialmente el mitema.

Funciona por ejemplo este tipo de fábula como mero recurso de introducción narrativa en el Sefer-Ha-Yashar ${ }^{100}$, en el que se cuenta que dicho libro es fruto de la colaboración de un oficial romano y de un viejo judío que habían trabado amistad durante el segundo saco de Jerusalén: al derribar los muros de una casa el oficial de Titus había dado con el escondite en el que se había refugiado el judío con una reserva de provisiones y una colección completa de todos los libros de la tradición hebrea (que se pasaba el tiempo estudiando); los dos hombres se fueron a Sevilla con esta biblioteca, y para resguardarla construyeron allí una casa grande en la que se encerraron para redactar, a partir del tesoro bibliofílico del que disponían, una especie de crónica profética de todo lo que había de suceder hasta la llegada del Mesías ${ }^{101}$. Recogida en Nápoles en el siglo XVI (después de una larga estancia en Egipto) por unos judíos del exilio que la editaron, esta crónica no es otra que el Libro de Yashar que, según el mismo prefacio, fue considerado como manual de sapiencia por los soberanos alejandrinos. La analogía con el Raziel y con los libros de Salomón se nota en la aptitud profética y omnisciente que acompaña la

100 Venecia 1544; Nápoles, 1552, etc. Véase The Book of Yashar, trad. ingl. M. N. Noah (Nueva York, 1840) (2." ed., 1972), pp. XV-XIX (introducción de la edición de Nápoles). Hay traducción francesa, por P.L.B. Drach, en el Dictionnaire des Apocryphes de Migne (Paris, 1858), 2, c. 1070 y ss., reeditada en 1981 (Le Livre du Juste Yaschar, Monaco: ed. du Rocher). El libro es de origen medieval (s. XII o XIII) y probablemente italiano, aunque se creyó durante mucho tiempo que, como afirma su introducción, fue compuesto en España en la antigüedad. En otros contextos el "libro de Yashar" aparece más bien como una especie de libro mítico "of which this Tora of ours is not more than a single line" (Yalqut ha Makhiri, traducido por R. Patai in Gates to the Old City. A Book of Jewish Legends, Northwale, New Jersey-Londres: J. Aronson, 1988), p. 417 ("Elijah and the Messiah").

101 En realidad el Yashar es una crónica (paralela a la Biblia, aunque con muchas adiciones y variantes extravagantes) de los hechos de los primeros héroes bíblicos. 
posesión del libro, en la ubicación más o menos recóndita del mismo, en la idea de la condensación en un libro único del saber multiforme contenido en toda una biblioteca y en la transmisión del saber oculto de un pequeño grupo de iniciados a otro.

Más claras aún que esta reutilización apócrifa del cuento-tipo del libro escondido-descubierto son las versiones orales modernas de la leyenda hasídica en la que se reconstruye y desarrolla el mito del libro de Raziel resumido en el Zohar para establecer una continuidad entre la revelación celeste otorgada a Adán y la que recibieron, después de los Patriarcas y Profetas de Israel, los fundadores del hasidismo (es decir, esencialmente el Baal Shem Tov). Se supone en este ciclo legendario que, después de la muerte de Adán, el "Libro de los Misterios" que Raziel le había comunicado en el jardín del Edén desapareció: le fue revelado a Enoch, en un sueño, que dicho libro se encontraba en una cueva, donde lo halló para que, a continuación, se transmitiese de profeta a profeta hasta Salomón. Finalmente, desapareció otra vez cuando se destruyó el Templo.

En realidad tal libro se halla ocultado y "encantado" en una caja de oro dentro de una cueva, y sólo lo pueden encontrar y consultar de vez en cuando algunos santos hombres, beneficiarios de la correspondiente visión o revelación, con tal de no revelar su ubicación y de volver a ponerlo en su escondite después de leerlo. A pesar de las empresas nefandas de un hechicero que trató, mediante engaño, de apoderarse del libro, un tal Rabí Adán tuvo acceso a él y lo pudo comunicar a Israel ben Eliezer, el Baal Shem Tov, máximo fundador del movimiento hasídico ${ }^{102}$. En estos relatos, como en el Zohar, se insiste sobre el carácter evanescente del Libro sobrenatural, al que constantemente los ángeles malos tratan de robar, y que se le escapa (o le es quitado) a quien no se muestra digno de poseerlo ${ }^{103}$. También pondera este tipo de leyenda

102 Howard Schwartz (ed.), Gabriel's Palace. Jewish Mystical Tales (Nueva YorkOxford: Oxford University Press, 1993), pp. 183-189 y 325 y ss. (notas): n. ${ }^{\circ} 92$ y 93 ("The Book in the Cave" y "The Prince of Fire"), sacado del Shivbei ha-Besht de Rabí Dov Ben Samuel (Europa oriental, s. XIX, traducido en Dan BEN AMOs, J. MinTZ (eds.), In Praise of the Baal Shem Tov : the earliest collection of legends about the founder of Hasidism (Shivbei ha-Besht), Bloomington, 1970). Véase también en la colección de H. SCHWARTZ, pp. 74 y ss.; y 292 y ss., n. ${ }^{\circ} 26$ ("The Book of Adam"), pp. 77 y ss. y p. 294: n. 29 ("The Book of Flying Letters" = Zohar I, 216 b-217 a), pp. 156 y ss.; y p. 318: n. 76 ("The Flying Letters"). Para la transmisión del Libro de los Misterios al Baal Shem Tov véase también Martin BuBER, Les Récits Hassidiques (Monaco: Ed. du Rocher, 1978), pp. 84-86; véase ibid., p. 437 ("L'enseignement secret"), la alusión a otro "libro oculto", "El Libro Anterior", en el que se revela lo que Dios estaba haciendo antes de la Creación...

103 Cf. el motivo de las "letras volantes" en el Zohar (véase nota anterior) y, en la narrativa folklórica judeo-española, el tema del rabí desposeído del manuscrito sapiencial 
rabínica - que pertenece al género literario-exegético del midrash encadenado (en el que se ensartan una serie de midrashim reunidos por un mismo motivo o personaje) - el tema de la transmisión oculta, que establece y revela vínculos secretos, a través de la historia, entre figuras y acontecimientos aparentemente dispersos, cuya subyacente continuidad pone de manifiesto la permanencia de la Alianza entre Dios y los más destacados representantes del pueblo elegido. El libro oculto viene a ser como el símbolo y el instrumento de este místico encadenamiento del tiempo relativo de la historia con el tiempo mítico y absoluto de los orígenes.

En determinados casos, el mitema ya no se aplica a un Libro sobrenatural sino a manuscritos más concretos aunque considerados como obras de gran alcance metafísico. Esto es lo que ocurrió por ejemplo en las tradiciones folklóricas relativas al destino de las obras de Maimónides: se imaginó que éstas se habían perdido después de la muerte del sabio porque las habían escondido sus enemigos debajo de la escalera de una sinagoga subterránea de Jerusalén. Sólo se descubrieron cuando al pisar los peldaños de dicha escalera algún rabí de notable santidad tropezó o se sintió detenido por una fuerza oculta ${ }^{104}$.

Como hemos comprobado, en la España aurisecular el motivo narrativo del descubrimiento de un escrito oculto tuvo formas múltiples y asumió funciones complejas.

Se encuentra en contextos novelescos (de tono onírico-fantástico en las novelas de caballerías, o irónico en el Quijote), en leyendas cronísticas y folklóricas (como se ve en el ciclo de la Casa Cerrada o Cueva de Hércules en Toledo, y en las consiguientes patrañas de magos encerrados en bibliotecas subterráneas) y en ficciones místicas paracabalísticas como la Revelación de San Pablo o los apócrifos del Sacromonte. Lo vimos funcionar tanto en obras literarias muy elaboradas como en elemen-

que le había entregado Elías (y de los poderes y saberes que este libro le confería) por falta de generosidad: R. HABOUCHA, Types and Motifs of the Judeo-Spanish Folktales (Nueva York-Londres: Garland, 1992), pp. 239-241 (tipo Aa-Th. 750 D, "Three Brothers Each Granted a Wish by an Angel Visitor").

104 Véanse las dos versiones hebreas traducidas en T. ALEXANDER y E. ROMERO (eds.), Érase una vez Maimónides. Cuentos tradicionales hebreos (Córdoba: El Almendro, 1988), pp. 218-221, y p. 264 (notas), n. ${ }^{\circ} 96$ y 97 ("El libro enterrado"). Nótese que en ambos casos el agente (y principal destinatario) de la revelación es un famoso cabalista. 
tales textos de magia talismánica, y hemos notado que en él se entrecruzan tradiciones árabes, judías y cristianas.

Ya se habían manifestado en el hermetismo alejandrino de la antigüedad helenística la vocación sincrética de este tipo de ficción y su aptitud para sintetizar, en el nivel de la fábula, las tendencias imaginarias e ideológicas de las tres grandes civilizaciones del Libro.

Es casi patético ver cómo, en el mismo momento en que esta convivencia cultural se está extinguiendo, al parecer para siempre, algunos nostálgicos, alucinados por ansias mesiánicas, tratan de revitalizar el mito, de reanudar los hilos cortados y dispersos.

El dispositivo imaginario más coherente en todo el acervo de patrañas que idearon los falseadores del Sacromonte no es otro, en efecto, que una refundición y sublimación neocabalística del tópico que acabo de rastrear. Se trata del mito de "la Verdad (o Certidumbre) del Evangelio" al que aluden tres de los apócrifos enterrados en el granadino monte de Valparaíso: en esta variante del tema joachimita del "Evangelio Eterno" se imagina que la Virgen comunicó a los apóstoles, el día de Pentecostés, un libro (la "Verdad del Evangelio") que Dios había hecho bajar del cielo para que les fuera entregado ${ }^{105}$; Santiago fue encargado de llevar ese libro a España y enterrarlo en un lugar indicado mediante un milagro. Allí quedará sepultado el celeste libro hasta que lo encuentre, siglos después, un santo sacerdote. Se reunirá más tarde, en Chipre, un concilio en el que participarán árabes $\mathrm{y}$, mediante la intervención de "una humildísima criatura" (¿un "puer senex"?) se traducirá y explicará el contenido del libro, anunciador de un tiempo feliz de reconciliación de las creencias y de las razas. Importa destacar un rasgo característico: paralelo a este cuento redencionista, en el que el libro es objeto material (a pesar de su procedencia divina), corre otra versión más claramente apocalíptica en la que el mismo libro de la Verdad del Evangelio, que parece tener alguna relación con las primeras tablas de Moisés, se aparece en su forma celestial a Santiago, en una visión que tiene lugar en el mismo monte santo donde ha enterrado las tablas que le entregó la Virgen. El apóstol ve un templo cerrado con candado de oro ${ }^{106}$ cuyas puertas se abren y dejan ver, entre una luz deslumbradora, un libro cerrado con siete sellos dorados. En este

105 En realidad, el libro presentado a los apóstoles por la Virgen aparece de forma doble: el texto original "escrito con la mano del poder con luz resplandeciente en tablas de piedra preciosa" y su traducción (realizada por María) "en tablas de plomo, sellada con el sello de Salomón" (Libro de la bistoria de la verdad del Evangelio, traducido del árabe, en M.J. HAGERTY, op. cit., pp. 119-130).

106 Cf. la "Casa Cerrada" de Toledo. 
libro se revelan "Sin dificultad, enigma ni metáfora" las diez partes de las tablas de Moisés que se han perdido por culpa de los Judíos (que "borraron de la escritura de Moisés diez señales") ${ }^{107}$.

Pero lo interesante es que este libro de la Verdad del Evangelio no se encontró en las oquedades del Sacromonte: sólo se hallaron un resumen de su historia pasada (hasta su enterramiento en Granada), el relato de la visión que de él tuvo Santiago, y un críptico "Libro Mudo" ${ }^{108}$. En realidad no se cumplió la profecía de su anunciado descubrimiento ¿Es que seguirá durmiendo en las profundidades del Valparaíso, o que se habrán contentado los artífices del engaño granadino con repetir miméticamente, al enterrar sus relaciones, y omitir las revelaciones que éstas dejaban esperar, el gesto de ocultación primordial operado por el Apóstol al esconder el celeste mamotreto y por Dios al borrar las letras de su primerísimo mensaje escrito?

¿O será acaso que no nos merecemos más que el ilegible y mudo compendio de un libro ideal o el recuerdo feliz de la visión de un libro cerrado y sellado? ${ }^{109}$

FRANÇOIS DELPECH

CNRS-CRES. París

107 M. J. HAGERTY, op. cit., pp. 253-255 (Libro de los misterios grandes que vio Jacobo Apóstol en el Monte Santo). Se alude aquí con toda probabilidad al mito talmúdico de la autodestrucción, por borramiento espontáneo, de lo que Dios había escrito en las primeras tablas de Moisés (las que el profeta rompió al ver el becerro de oro), mito que se reelabora en el Zohar mediante el motivo de las "letras volantes" (cf. supra n. 102 y 103). Se supone por lo tanto que el Libro de la Verdad del Evangelio contemplado por Santiago en su visión para-sinaítica del Sacromonte contiene la revelación mosaica primordial perdida, que se restituirá en los tiempos últimos (sus siete sellos indican su identidad con el libro del Apocalipsis de San Juan, V,1).

108 Se menciona otra vez el libro de la Verdad del Evangelio en uno de los apócrifos autoatribuidos a Tesifón, el Libro de los dones de galardón que se ha de dar a los que creyeren la Verdad del Evangelio (M. J. HAGERTY, op. cit., pp. 131-146).

109 No puedo despedirme de este ensayo sin mencionar con agradecimiento todo lo que su versión castellana debe a mi amigo José Manuel Pedrosa, que la revisó y le confirió mejor estilo. 
El tópico paratextual de la seudo-historicidad, de la atribución imaginaria y de la fingida traducción de un manuscrito perdido tuvo amplia difusión en la narrativa aurisecular. Suele asociarse a un cuento-tipo más o menos embrionario en el que se relatan las circunstancias del hallazgo del escrito oculto. En este artículo se estudian las relaciones de dicho estereotipo - también fundamental en las producciones apócrifas y en la literatura de Revelación- con la mitología subyacente en la magia talismánica. Se trata de poner en evidencia el arraigo de esta mitología en las tradiciones esotéricas judías y musulmanas tributarias de la corriente hermética, en la que confluyeron antiguas representaciones orientales relativas a la procedencia transcendente de la escritura y al carácter sagrado del Libro.

The pseudo-historicity, spurious attribution and alleged translation of a lost manuscript was a paratextual theme widely used in the Spanish literature of the Golden Age, usually associated with a taletype in which the author tells the circumstances of finding the lost text. Delpech focuses on the relations of such a theme - essential in apocrypha and in the literature of Revelation - to the mythology underlying talismanic magic. He argues that this mythology is rooted in some esoteric trends of Judaism and Islam that originated in the Hermetic Tradition, where ancient views of the East on the heavenly origin of writing and the holy nature of the book converged. 